\title{
The Permian to Cretaceous succession at Permpasset, Wollaston Forland: the northernmost Permian and Triassic in North-East Greenland
}

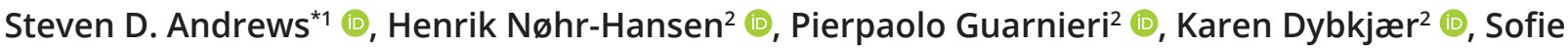 \\ Lindström² (i), Peter Alsen² (1)
}

${ }^{1}$ University of the Highlands and Islands, Inverness, UK, ${ }^{2}$ Geological Survey of Denmark and Greenland (GEUS), Copenhagen, Denmark

\begin{abstract}
Permian to Triassic outcrops in East Greenland diminish significantly northwards. Understanding the northward extent, and nature, of the Permian and Triassic successions has implications for regional palaeogeographic reconstructions and exploration in adjacent offshore basins. Examining the structural relationships between the basement, Permian, Triassic, Jurassic and Cretaceous successions can further our understanding of the tectonic evolution of the region. Here, we describe a hitherto overlooked section through the Permian to Cretaceous from central Wollaston Forland and consider its structural context. The western side of Permpasset forms the upthrown eroded crest of a horst block, which provides exposure of the earliest stratigraphic intervals in the region. The fractured Caledonian basement is overlain by evaporitic marine limestone facies of the Karstryggen Formation, which are succeeded by shallow marine sandstones assigned to the Schuchert Dal Formation, both Upper Permian. The overlying unit records a period of fluvial deposition and is not possible to date. However, an Early to Middle Triassic age (Pingo Dal Group) seems most likely, given regional eustatic considerations. This is, therefore, the most northerly record of Triassic strata in North-East Greenland. West of the horst structure, fine-grained sandstones and bioturbated siltstones of the Jurassic (Oxfordian) Jakobsstigen Formation are recorded. These were downfaulted prior to a prolonged hiatus after which both the Triassic and Jurassic strata were draped by Cretaceous shales of the Fosdalen Formation. The Cretaceous succession is overlain by a thick basalt pile of Eocene age, heralding the opening of the North-East Atlantic. Glendonites overlie Oxfordian siltstones at the base of the middle Albian Fosdalen Formation. These were likely winnowed from slightly older Cretaceous strata and overlie the hiatus surface between the Jurassic and Cretaceous. This is the first record of glendonites from the Cretaceous of East Greenland and they are interpreted to record the Circum-Arctic late Aptian - early Albian cooling event.
\end{abstract}

\section{Introduction and geological background}

The Permian and Triassic have received much attention where spectacularly exposed in Jameson Land, Scoresby Land, Traill $\varnothing$, Geographical Society $\varnothing$, Hold with Hope and Clavering $\varnothing$ (Clemmensen 1980a, 1980b; Surlyk et al. 1986; Christiansen et al. 1993; Stemmerik 2001; Andrews et al. 2019,

\author{
*Correspondence: steven.andrews914@ \\ gmail.com \\ Received: 12 Jan 2021 \\ Accepted: 20 May 2021 \\ Published: 23 July 2021 \\ Keywords: Cretaceous, East Greenland, \\ glendonites, Permian, Triassic

\section{Abbreviations:} \\ MIERL: Ministry of Industry, Energy, \\ Research and Labour \\ GEUS: Geological Survey of Denmark and \\ Greenland
}

GEUS Bulletin is an open access, peerreviewed journal published by the Geological Survey of Denmark and Greenland (GEUS). This article is distributed under a CC-BY 4.0 licence, permitting free redistribution, and reproduction for any purpose, even commercial, provided proper citation of the original work. Author(s) retain copyright.

Edited by: Mette Olivarius (GEUS Denmark)

Reviewed by: Ashton Embry (Geological Survey of Canada, Canada), Tore Grane Klausen (Petrolia NOCO AS, Norway)

Funding: See page 13

Competing interests: None declared

Additional files: None provided 
2020a, 2020b; Clemmensen et al. 2020). However, those sections lying further north on Wollaston Forland have seen little, if any, concerted study (Fig. 1). The nature of the northward continuation of the Permian and Triassic successions has important implications for palaeogeographic reconstructions and our understanding of adjacent offshore basins, and as such these outcrops have an increased significance. Maync (1942) described the Permian succession of Wollaston Forland, but with the advancement of our understanding of the regional setting and stratigraphy, a number of questions existed about this remote and seldom visited outcrop. Of particular interest is the enigmatic clastic succession that overlies the Permian limestones. Furthermore, examining the structural relationships among the basement, Permian, Triassic, Jurassic and Cretaceous successions can further our understanding of the tectonic evolution of the region.

This work was undertaken as part of a larger MIERL (Ministry of Industry, Energy, Research and Labour) and GEUS (Geological Survey of Denmark and Greenland)-led regional scale mapping project, which included examination of the full Permian to Eocene succession and the investigation of the associated structural elements across the Wollaston Forland. As part of this project, time was spent examining the Permian to Paleocene-Eocene stratigraphy and associated structure of Permpasset, central Wollaston Forland. The results of these investigations are presented here. This includes an assessment of the stratigraphy, which is thought to include Permian, Triassic, Jurassic Cretaceous and Paleocene-Eocene strata, capped by a thick plateau basalt succession. The exposure of the deeper stratigraphic levels recorded in Permpasset occurs due to the presence of the $\mathrm{N}$-S-orientated Permpasset Fault, which downthrows to the east and exposes the eroded crest of the Permpasset horst block, including the succession described here. The western margin of the horst is defined by an NE-SW-orientated fault, which converges on the Permpasset Fault to the north. A further E-W-orientated fault divides the horst but appears to have limited displacement. These structures and their temporal relationships are described in detail in the next sections.

\section{Methodology}

Geological mapping was undertaken by foot traverse supported by 3D-photogeology in the GEUS photogrammetry lab (Sørensen \& Dueholm 2018; Sørensen \& Guarnieri 2018) based on new oblique photos acquired in 2017 (Olsen \& Jakobsen 2018). Sedimentological logging was undertaken at 1:40 scale where exposures were of good quality and at 1:2000 scale where exposures were poor. Samples of fine-grained lithologies were collected throughout the successions for palynological analysis.
Macropalaeontological specimens were also collected for identification. Palynological samples were prepared using standard laboratory techniques (Poulsen et al. 1990) before being counted and identified.

\section{Sedimentology and stratigraphy}

Permpasset provides the most easterly exposure of Palaeozoic strata in Wollaston Forland. The succession recorded occurs as a small area of outcrop on the west side of the valley at the apex of the pass. The Permpasset Horst is defined by the Permpasset Fault to the east and in the west by an NE-SW-aligned fault (Figs 1, 2A). Sections were logged through the eroded horst crest and to the north-west in the hanging wall of the NESW-trending fault. These are described in turn below.

\subsection{Permpasset Horst}

Description. The lowermost unit is $36 \mathrm{~m}$ thick (Fig. 3) and rests on heavily fractured Caledonian basement mostly comprising granite and quartzite. The initial $15 \mathrm{~m}$ is poorly exposed, but the likely lithology is indicated by large blocks of shell-rich limestone, which are unlikely to have travelled far. The shell material includes abundant productid brachiopods and crinoids, which vary between different beds from heavily fragmented to almost complete. Overlying this, initially poorly exposed section is a prominent cliff-forming succession. The base of the cliff comprises brecciated limestones, which display rounded clasts with minor intercalations of laminated limestones $(3 \mathrm{~m})$. These transitions upward to blocky brecciated limestone and increase volumes of gypsum (Fig. 2B), which eventually form the dominant lithology $(4 \mathrm{~m})$. Blocks up to several metres are recorded. An uneven surface is then infilled by bedded selenite (Fig. 2C), which forms a unit up to $1 \mathrm{~m}$ thick before being overlain by a further $4 \mathrm{~m}$ of poorly exposed brecciated limestone and gypsum, again displaying an uneven upper surface. These are overlain by $8.5 \mathrm{~m}$ of laminated limestone devoid of shell material (Fig. 2D). Minor undulatory lamination is recognised in the basal $2 \mathrm{~m}$ (Fig. 3).

The middle unit reaches a thickness of $23 \mathrm{~m}$ and comprises shell-rich, fine-grained, buff-coloured sandstones and grey limestones intercalated with coarsely laminated grey limestones forming beds between 0.1 and $0.3 \mathrm{~m}$ thick. The shell material is again dominated by productid brachiopods with beds often containing a mixture of both heavily fragmented material as well as complete valves (Fig. 4A). Articulated specimens are rare. Horizontal lamination predominates, and some beds display erosive bases. Overall, an upward increase in both the sandstone component and shell material occurs in this unit (Fig. 3). Minor bioturbation is also recognised towards the unit top. 


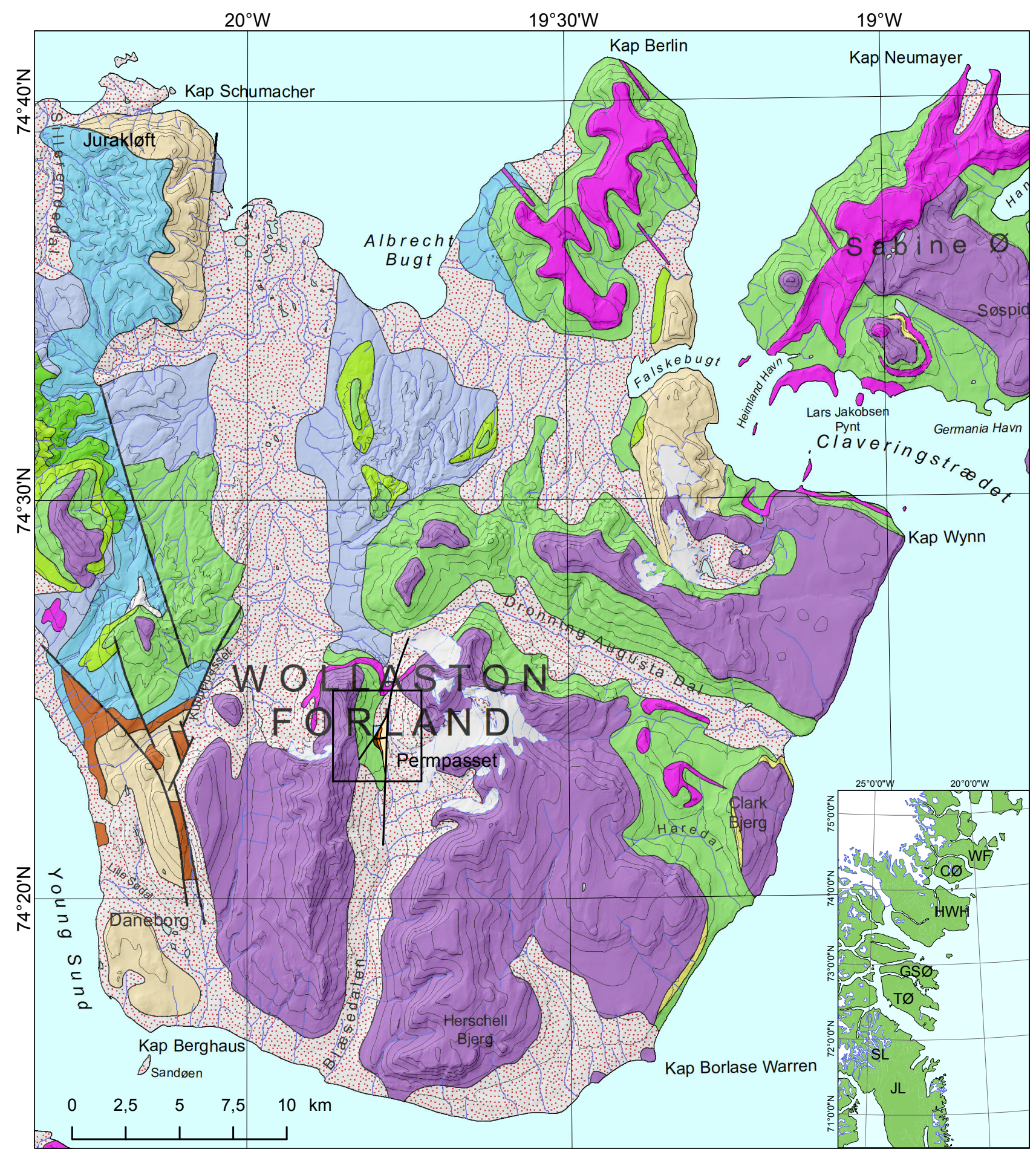

\section{Legend}

\begin{tabular}{|l|l|l|}
\hline \multirow{2}{*}{ Ice and perennial snow } & Tertiary & \multicolumn{2}{c|}{ Cretaceous } \\
\hline Sea & Dykes and sills & Stratumbjerg-Fosdalen Fms \\
\hline Q Quaternary & Plateau basalts & Palnatokes Bjerg Fm \\
& Sandstones & Lindemans Bugt Fm \\
\hline
\end{tabular}

\section{Jurassic/Triassic Permian}

\begin{tabular}{lr} 
Jakobsstigen Fm & Foldvik Creek Group \\
Pelion Fm & Caledonian basement \\
\hline Pingo Dal Gp & Quartzites and migmatites
\end{tabular}

Fig. 1 Geological map of Wollaston Forland (modified after Escher 2001). The black-lined box marks the position of the map illustrated in Fig. 7. The inset map indicates the position of Wollaston Forland (WF) on the East Greenland coast as well as other regions mentioned in the text: $\mathbf{C} \varnothing$ : Clavering $\varnothing$. HWH: Hold With Hope. GSØ: Geographical Society $\varnothing$. TL: Traill $\varnothing$. SL: Scoresby Land. JL: Jameson Land. 

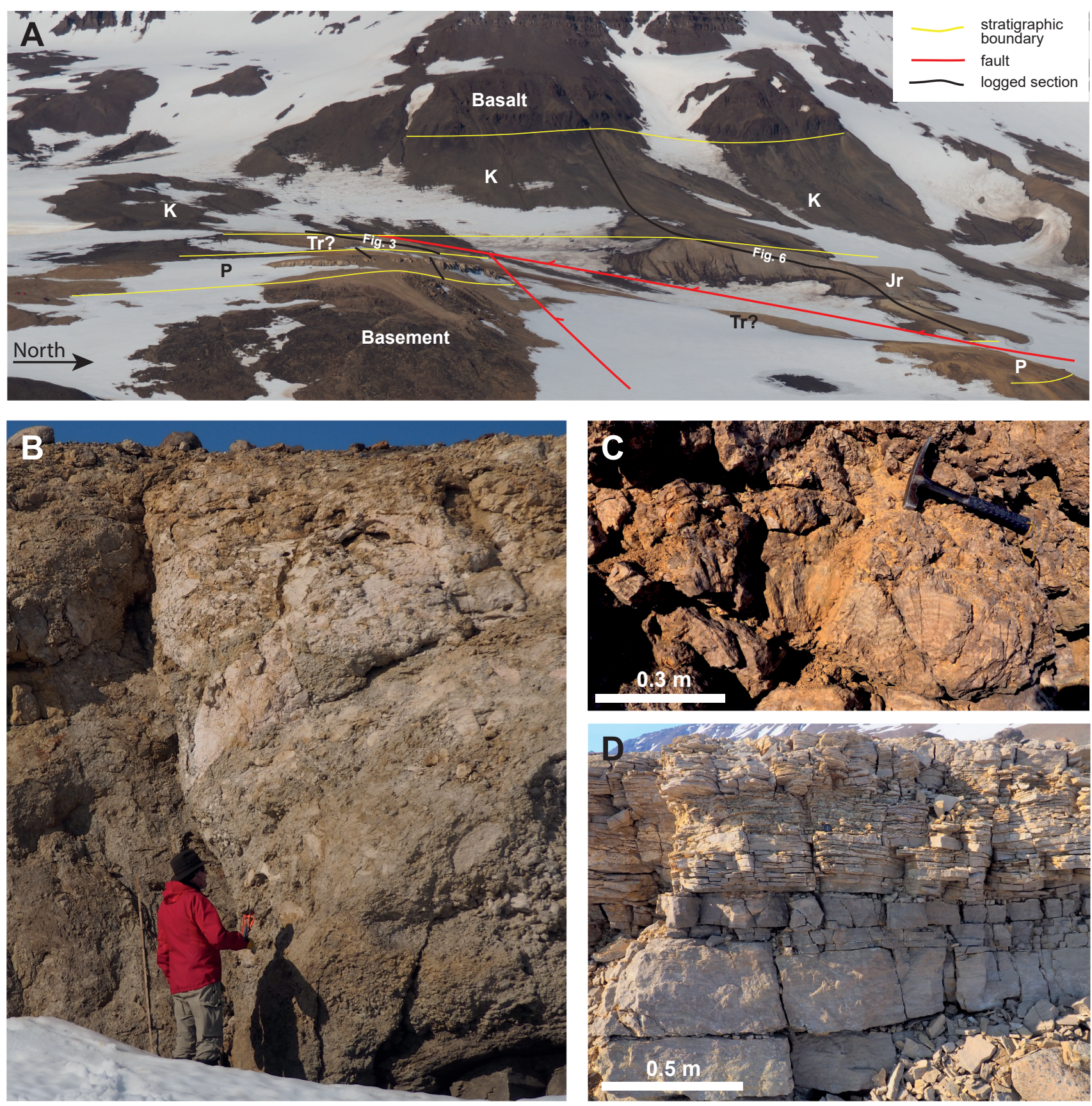

Fig. 2 Overview of the Permpasset outcrop and photographs illustrating the key lithologies of the Permian succession. A: view west across Permpasset illustrating the stratigraphic and structural relationships and the position of the logged sections provided in Figs 3 and 6. P: Permian. Tr: Triassic. Jr: Jurassic. K: Cretaceous. B: Brecciated limestone and gypsum, including progressively larger blocks upwards (Karstryggen Formation). C: Bedded selenite overlying the first brecciated interval (Karstryggen Formation). D: Bedded limestones recording a deepening and freshening of marine conditions, perhaps forming a correlative of the Wegener Halvø Formation.

The base of the topmost unit is marked by a distinct coarsening with medium- to coarse-grained pebbly sandstones recognised (Fig. 3). Trough cross-bedding and planar cross-bedding also become common (Fig. 4B), forming sets up to $0.4 \mathrm{~m}$ thick and indicating a broadly southerly directed flow. Minor bioturbation is recognised, but there is a complete lack of shell material. The lowermost $3 \mathrm{~m}$ of sandstones is succeeded by a poorly exposed recessive section of around $7 \mathrm{~m}$ comprising red to orange coloured fine-grained/muddy material. This is overlain by a further $23 \mathrm{~m}$ of fine- to medium-grained, feldspathic, buff-coloured sandstones, again displaying abundant trough cross-bedding. Erosive bed bases, often defined by pebble and mudstone rip-up lags, are also common. Despite the pale appearance of these uppermost sandstones, when a fresh surface is exposed, a much darker colouration is noted. 


\section{Permpasset Central}

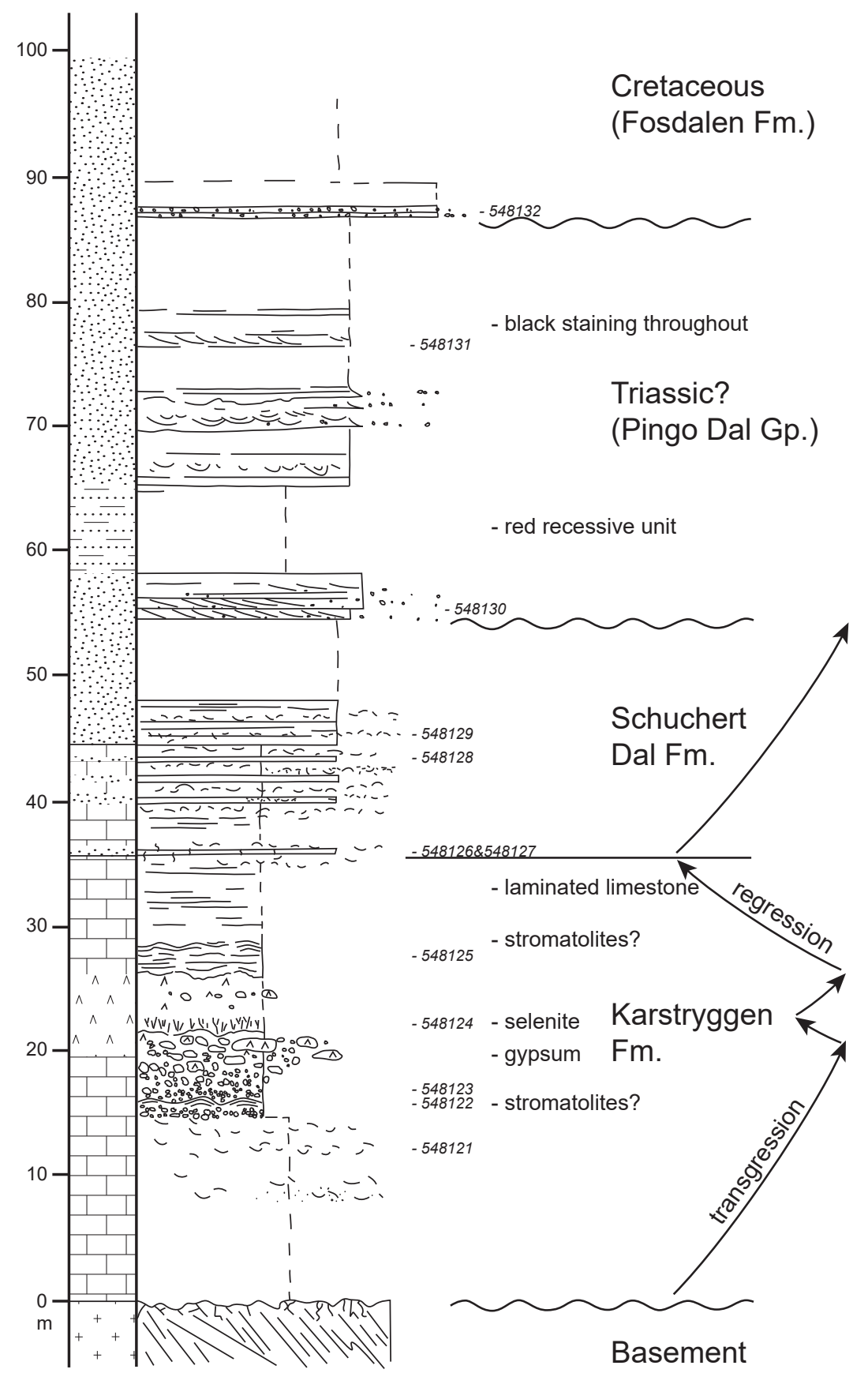

\begin{tabular}{llllllllll}
\hline & 1 & I & I & I & I & I & I & I & I
\end{tabular}

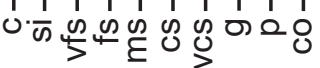

\section{(Fosdalen Fm.)}

(Pingo Dal Gp.)

red recessive unit

\section{Basement}

Fig. 3 Logged section from the central outcrops of the Permpasset exposures. The location of the section is indicated in Fig. 2A. Sample numbers are included adjacent to the log.

\begin{tabular}{|c|c|c|c|}
\hline \multicolumn{4}{|l|}{ Key } \\
\hline 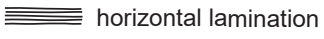 & $\hat{\wedge}^{\wedge} \bigotimes$ evaporites (gypsum) & \begin{tabular}{l|l}
${ }^{2}$ & \\
\end{tabular} & limestone \\
\hline$\longrightarrow$ planar cross-bedding & 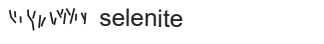 & $\wedge \wedge$ & evaporite \\
\hline ఝ心 trough cross-bedding & s,sss bioturbation & $\because \because \because \because$ & \\
\hline ఓここ convolute lamination & $\cdots$ bivalves & $\cdots \cdots \cdots$ & siltstone \\
\hline$\therefore \therefore$ pebbles & & $\begin{array}{r}1 \\
+\quad+ \\
\end{array}$ & basement \\
\hline
\end{tabular}



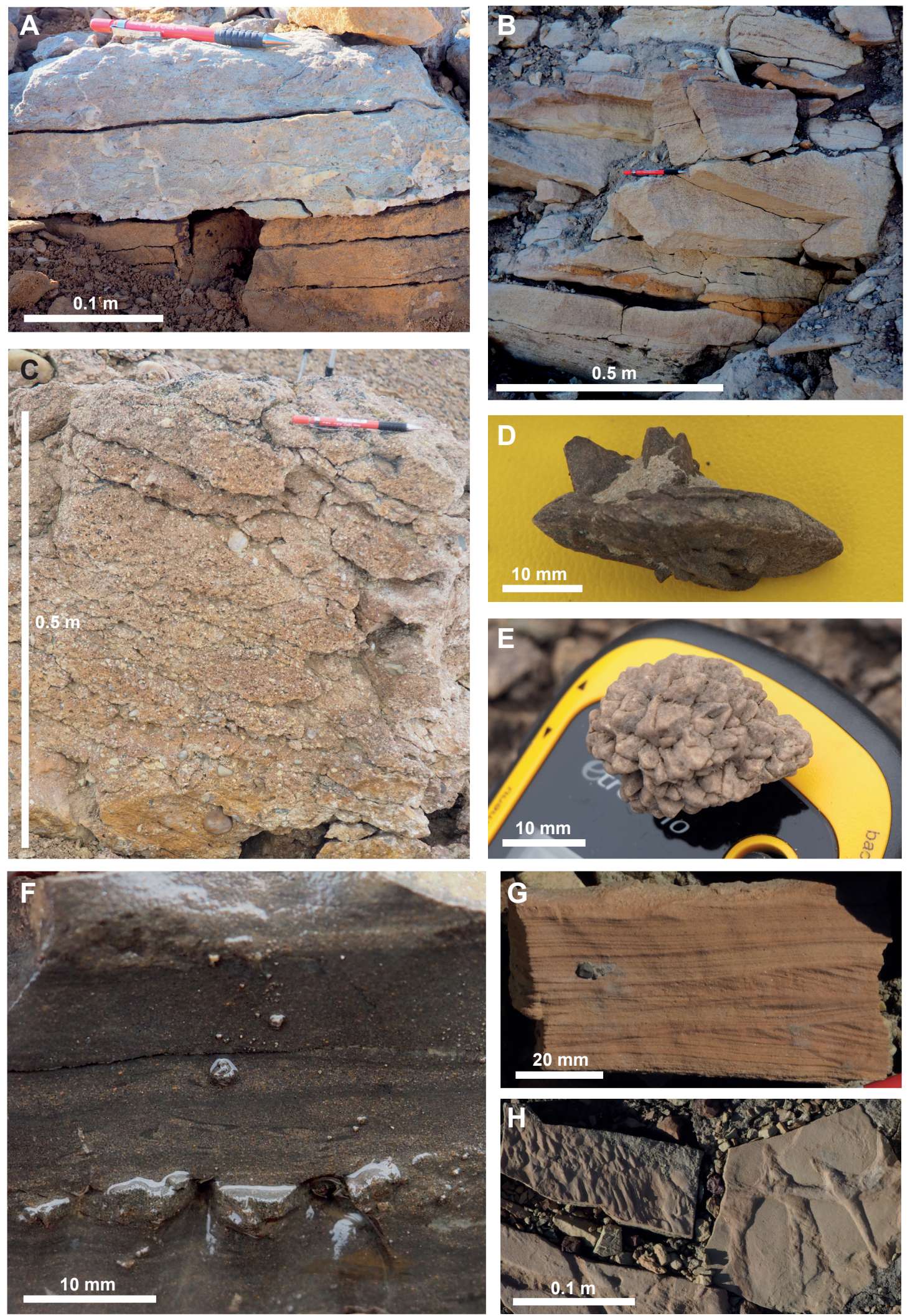

Fig. 4 Photographs illustrating the key lithologies of the uppermost Permian, and the Triassic, Jurassic and Cretaceous stratigraphy. A: Interbedded shelly limestones and sandstones forming the top of the Permian succession (Schuchert Dal Formation). B: Buff-coloured planar and trough cross-bedded sandstones with intraclast lags commonly present at bed bases (Triassic Pingo Dal Group?). C: Pebbly sandstone with abundant rounded quartz clasts and occasional sandstone clasts forming the base of the Jurassic (Jakobsstigen Formation). D and E: Different glendonite forms from the base of the Cretaceous succession. F: Graded lamination and contorted intraclasts within the siltstones of the Fosdalen Formation. G: Current ripples with possible signs of storm reworking in sandstone beds weathering out of the Fosdalen Formation. H: Flute marks and Thalassinoides ichnofossils preserved on bed bases in the Fosdalen Formation. 
This succession is capped by a thin ( $2 \mathrm{~m}$ ) unit of very coarse, quartz rich, pebbly sandstones, above which the slopes are recessive, potentially indicative of finer-grained facies.

Interpretation and stratigraphic assignation. The brecciated and evaporitic nature of the lowermost unit most closely resembles the Karstryggen Formation as originally described from the Jameson Land region (Surlyk et al. 1986). This is also consistent with the abundant Late Permian marine fauna. The features described are interpreted as evidence of a marine environment where exposure led to the development of brecciation through karstification during subaerial exposure. The first brecciated interval is overlain by bedded selenite, suggesting not only renewed flooding of the region but also the development of strongly evaporative conditions, most likely reflecting a highly restricted setting. The second brecciated interval is topped by laminated limestones, which suggest a return to deeper water, non-evaporative conditions. This is consistent with the trends observed elsewhere in East Greenland, where the Karstryggen Formation is topped by the Wegener Halvø Formation reefal limestones, and the black shales of the Ravnefjeld Formation (Surlyk et al. 1986; Christiansen et al. 1993; Stemmerik 2001). The laminated limestones described here, although likely to correlate with the deepening conditions recorded by these units, are considered too thinly developed to define as a separate formation.

The middle unit is interpreted to reflect a gradual return to shallower water conditions, initially with the introduction of occasional shell-rich sandy beds before facies become dominated by horizontally laminated sandstones, which, alongside the fragmentation of shell material, provide evidence for high-energy conditions, most likely reflecting a shallow marine environment. The sandy nature of this unit and the regressive signature are most similar to the Schuchert Dal Formation described to the south, which occurs as both shallow marine and turbiditic facies (Surlyk et al. 1986; Kreiner-Møller \& Stemmerik 2001).

The topmost unit is marked by its complete absence of shell material. The presence of planar and trough cross-bedding, alongside erosive bed bases containing mudstone rip-up clasts and the red to orange colouration of the poorly exposed intervening finer-grained units is suggestive of a continental, fluvial depositional environment.

The age of this $32 \mathrm{~m}$ thick succession is problematic with Permian, Triassic or even Jurassic ages being possible. No Late Permian fluvial deposits have been reported from East Greenland. Furthermore, this period is characterised by falling sea levels and the development of a hiatus, particularly outside of basinal areas (Surlyk et al. 1986). Therefore, the preservation of fluvial deposits at this time seems unlikely. The Early Triassic is marked by a major transgression, leading to the widespread deposition of the marine Wordie Creek Formation (Seidler et al. 2004). No evidence is found in the uppermost unit described here for marine conditions. To the south, on Clavering $\varnothing$, the Wordie Creek Formation comprises pebbly buff sandstones and green-grey shales. Although the facies described here do resemble these buff sandstones, they lack the hummocky cross stratification noted in the Clavering $\varnothing$ examples, and the intervening finer-grained facies appear to be red-orange in colour, favouring a continental origin. The next candidate would be the continental, Early to Middle Triassic Pingo Dal Group. The depositional environment and stratigraphic position would favour the interpretation of this unit as the Pingo Dal Group, but one further option requires consideration, the Jurassic, and more specifically, the continental Bastians Dal or Bristol Elv formations. However, both these units are characterised by abundant organic/woody debris and their high compositional maturity, whereas the topmost unit described here is devoid of organic remains and also appears to be highly feldspathic. Therefore, the simplest interpretation that can be made would place this unit as the Early to middle Triassic Pingo Dal Group.

The age of the pebbly sandstone, which caps the exposure, is unknown, but it is lithologically distinct from the underlying sandstones. The overlying recessive slopes most likely represent fine-grained facies of the mid-Cretaceous strata, which blanket the region. Therefore, the pebbly sandstone could be interpreted as representing condensed deposits, which overlie the unconformity surface prior to the onset of mid-Cretaceous deposition.

Evidence for reworked Triassic in the region. Although the unit described above appears isolated, with respect to the regional distribution of Triassic strata, reworked Triassic palynomorphs have been recorded in outcrop samples of the Jurassic Pelion and Payer Dal formations in the Jurakløft area, northern Wollaston Forland. These formations are dated by ammonites and dinoflagellate cysts to the Bathonian-Callovian and Oxfordian, respectively (this study). The reworked palynomorphs are generally darker in colour than the Jurassic dinocysts but differ little in appearance from the Jurassic spores and pollen. Identified Triassic pollen includes Protodiploxypinus gracilis, Podosporites amicus, Triadispora sp. and Aulisporites astigmosus (Fig. 5). The recovered Triassic spore/pollen assemblage is believed to indicate reworking of Late Triassic, Carnian, strata. This is based primarily on the biostratigraphic distribution of Aulisporites astigmosus, which is more or less confined to the Carnian in the Boreal area (Vigran et al. 2014; Paterson \& Mangerud 2015). On Svalbard and in the Barents Sea, Protodiploxypinus sp. has an acme in the latest Carnian, 


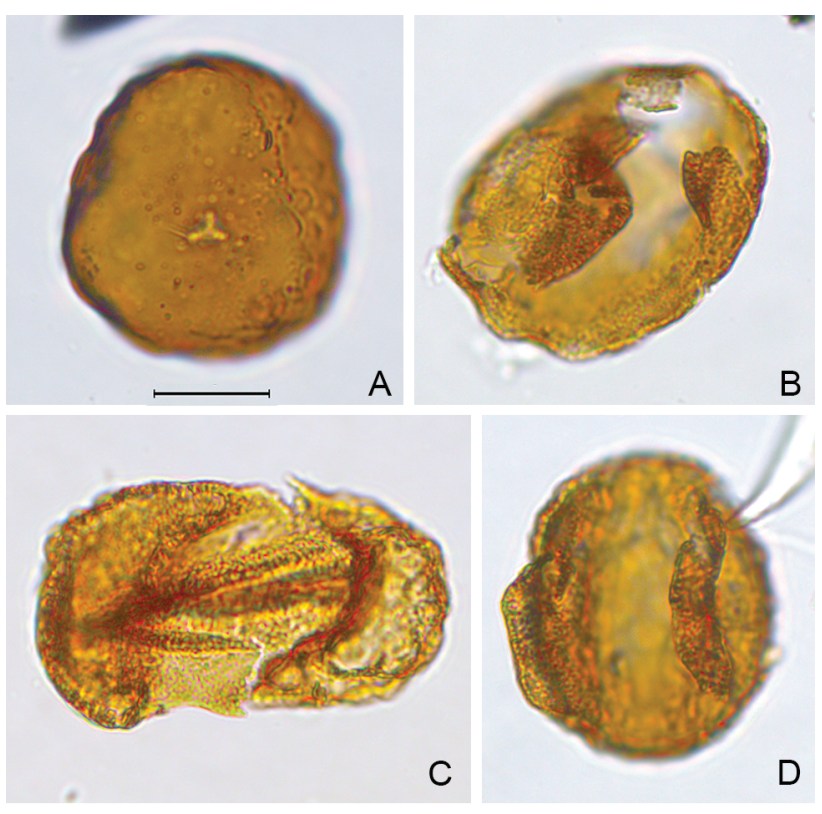

Fig. 5 Examples of reworked Triassic pollen. Taxon name is followed by sample and slide number and England Finder coordinates. The scale bar is $20 \mu \mathrm{m}$. A: Aulisporites astigmosus, 589748:4, U58/3. B: Protodiploxypinus gracilis, 589757:5, H18/1. C: Lunatisporites sp., 589754:5, H53/2. D: Protodiploxypinus sp. cf. P. gracilis, 589757:4, S43/1.

where it occurs with sporadic Aulisporites astigmosus (Paterson \& Mangerud 2015, 2020). In the Jurakløft assemblages, $A$. astigmosus is one of the most common reworked palynomorphs. This may indicate that strata equivalent of the Carnian Pluvial Episodes (e.g. Dal Corso et al. 2020) were once present in the area. Farther south, on Jameson Land, palynological assemblages interpreted to represent the Carnian Pluvial Episode appear to be lacking Aulisporites astigmosus (Andrews et al. 2014). However, further north on Spitsbergen $A$. astigmosus sometimes makes up $>20 \%$ of the late Julian assemblages from Tschermakfjellet Formation (Mueller et al. 2016).

\subsection{North West of the Permpasset Horst}

Description. This section lies to the north-west of the horst where strata have been downfaulted to the west (Fig. 2A) and comprise three distinct units. The base of the section comprises a very coarse-grained, quartzrich, pebbly sandstone containing pebbles up to $5 \mathrm{~cm}$ (Fig. 4C). Pebble lithologies are dominated by quartz but minor schist/gneiss and sandstone clasts are recognised. Exposure is poor above this coarse-grained unit, but the recessive slopes are composed of medium to fine-grained sands, which continue upwards for $25 \mathrm{~m}$ (Fig. 6). These are overlain by interbedded light grey silty mudstones and fine-grained, poorly consolidated sandstones, which occasionally contain small pebbles (2-5 $\mathrm{mm})$. Bioturbation and bivalve moulds are recognised within this unit as well as occasional large wood fragments. Upwards, sandstone beds become less common but bioturbation appears to increase in intensity producing a mottled appearance to the silty mudstones. Coarsening-upward cycles (10-25 m thick) are recognised within this unit, with each cycle capped by siltstones to sandy siltstones. Large carbonate concretions (0.5-1 m) are also recorded throughout, but with a tendency to concentrate towards the top of the cycles described. The concretions themselves often preserve original sedimentary features, which existed within the silts. A distinct bench overlain by a $10 \mathrm{~m}$ thick mudstone marks the top of this unit.

The topmost unit is marked by very dark to black mudstones at its base. These are initially bioturbated, but upwards bioturbation dies out. The base of this unit is further marked by the presence of glendonites, which are common in a single interval (Figs 4D, E). Belemnite fragments are also recorded at this horizon. The dark colouration continues for $55 \mathrm{~m}$. In this interval, bioturbation is not common, but siderite nodules and carbonate nodules displaying cone-in-cone structure are noted. Rare stream-worn sections reveal 1-10 mm scale lamination displaying grading and containing 1-4 $\mathrm{mm}$ deformed mudstone rip-up clasts at laminae bases (Fig. 4F). Above these dark-coloured mudstones, a general lightening of tone, accompanied by increased silt content and the return of bioturbation, is noted. This forms a further $87 \mathrm{~m}$ of section before the base of the overlying basalts is reached (Fig. 6). Further sedimentological detail for this succession can be gleaned from a laterally correlative section examined to the northwest. Here, the bioturbated siltstones contain better defined coarsening-upward cycles on a 10-20 m scale (Fig. 6). These cycles are often topped with very fine- to fine-grained sandstone beds up to $0.1 \mathrm{~m}$ in thickness. Bed bases display flute marks (Fig. $4 \mathrm{H}$ ) and occasional load structures. Internally, current rippling and possible hummocky cross-stratification (Fig. 4G) are noted alongside bioturbation, including well-developed Thalassinoides (Fig. 4H).

The base of the basalts, which overlie the sedimentary succession, is uneven, and in places, large grey carbonate nodules and coalified wood fragments appear to be embedded within a claystone matrix (PaleoceneEocene?), which is, in turn, overlain by autobreccia, which appears to incorporate some of the underlying sediment.

Interpretation and stratigraphic assignation. The presence of bivalve casts, abundant bioturbation as well as the presence of acritarchs and dinocysts recognised during micropalaeotological analysis favour a marine environment for the lowermost unit of this section. A Callovian age has been ascertained from the top of this 
Permpasset W

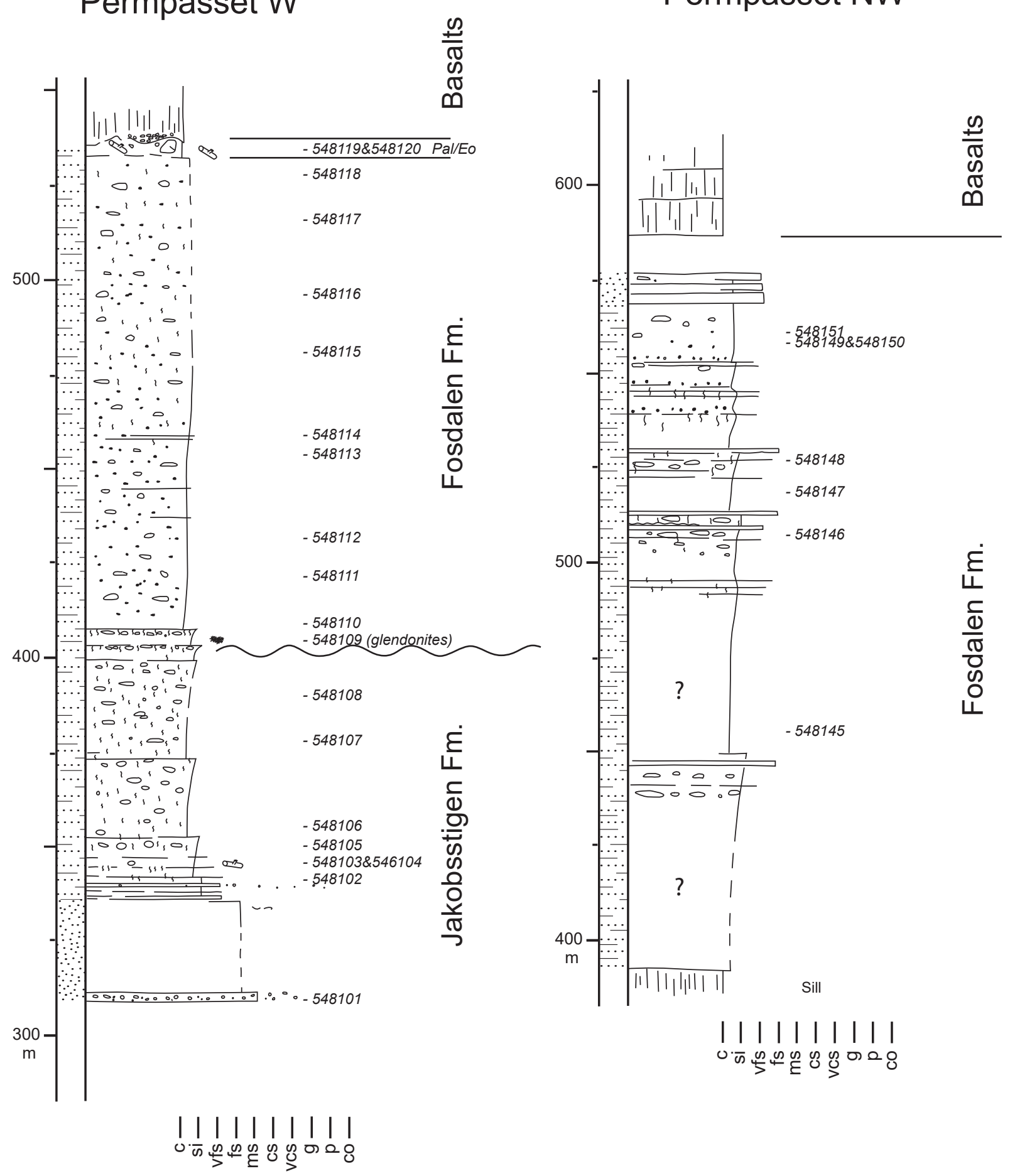

\section{Permpasset NW}

ס

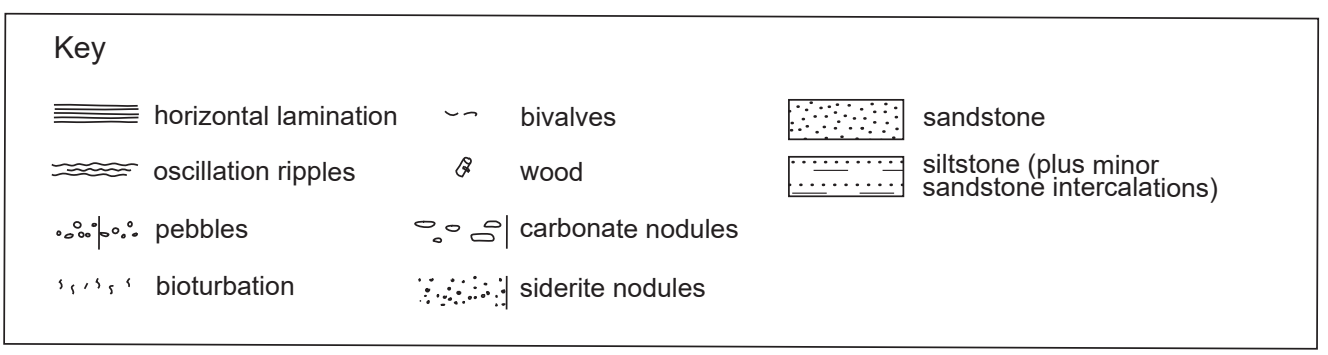

Fig. 6 Logged sections from the northern portion of Permpasset. The location of Permpasset W is provided in Fig. 2A. Pal/Eo: Paleocene or Eocene. Sample numbers are included adjacent to the log. 
unit based on the recovery of the acritarch Veryhachium sortehatense, which has been reported from Callovian at Hold with Hope by Piasecki et al. (2004). The presence of sandstone clasts within the basal pebbly sandstone suggests that the Permian or Triassic sandstones on the adjacent horst may have been exposed and were being reworked at this time. This would also be in accord with the widely recognised Middle Jurassic rifting and associated erosion of fault block crests (Surlyk 1990; Surlyk \& Korstgård 2013).

The initial sand-rich strata found at the base of the lower unit gradually give way to intensely bioturbated siltstones (Fig. 6). An overall deepening trend is suggested, resulting in both a reduction in sand supply and energy. Regular coarsening-upward cycles overprint the overall fining signature. The poorly preserved dinocysts, Pareodinia prolongate and Nannoceratopsis pellucida, recovered from the very top of this unit suggest a lower to middle Oxfordian age. Therefore, this unit can be assigned to the Jakobsstigen Formation. Vosgerau et al. (2000) recognised 0.1-19 $\mathrm{m}$ alternations between shallow marine and coastal plain conditions in the Jakobsstigen Formation. The cycles recorded here may be a distal equivalent of these. However, land was likely not too far away, as indicated by the presence of large wood fragments. As age constraints are only available for the top of this unit, it could be speculated that the lowermost, sand-rich portion corresponds to the Pelion Formation on the basis of its lithological affinity with this Callovian unit. However, the poor quality of the outcrop and the lack of biostratigraphic control do not provide confidence in this interpretation.

The base of the topmost unit is marked by a distinct darkening in the facies, suggesting a change to poorly oxygenated conditions. This is further evidenced by the absence of bioturbation. Also recorded at the contact with the underlying unit is a glendonite-bearing horizon. Micropalaeotological analysis of this unit provides a middle Albian age, indicated by the presence of the Lithosphaeridium arundum and the Chichaouadinium vestitum subzones of Nøhr-Hansen (1993) and Nøhr-Hansen et al. (2020). However, the most likely date for the glendonites is late Aptian - early Albian during which time a cooling event is recorded throughout the Arctic (Rogov et al. 2017). This would, therefore, be the first reported occurrence of glendonites of this age in East Greenland. Their presence at this stratigraphic boundary, which appears also to represent a significant hiatus, is most easily accounted for if they were winnowed from slightly older Cretaceous strata, forming a transgressive lag, prior to the deposition of the Middle Albian succession. This would explain the juxtaposition of quite different glendonite forms within a single horizon (Figs 4D, E). This is consistent with the eastward increase in the erosion of Aptian strata across Wollaston Forland as reported by Bjerager et al. (2020). Above the dark basal portion of this unit, the presence of intense bioturbation, including Thalassinoides, is suggestive of marine conditions. The presence of thin sandstone beds with flute-marked bases and containing current ripples is consistent with turbidite deposition. Minor wave reworking may have also occurred during storm activity, as evidenced by the presence of hummocky cross-stratification. Graded lamination within the siltstones and micro-scale intraclasts provides evidence for more dilute underflow activity. The cycles recognised, therefore, likely reflect the progradation and retrogradation of more marginal systems during successive transgressive-regressive cycles, which resulted in the advance and retreat of associated turbidite systems. The Middle Albian age determined for this unit places it within the Fosdalen Formation.

\section{Structure of the Permpasset Horst}

Permpasset is characterised by three sets of normal faults (Fig. 7A). Cross-cutting relationships demonstrate that the most recent activity occurred along the almost N-S trending Permpasset Fault (Haller 1971; Surlyk \& Korstgård 2013) as indicated by the displacement of the Palaeogene basalts, which are down-faulted to the east. The Permpasset Fault cuts a NE-SW-trending fault. A subsidiary E-W fault is bracketed between these two faults. Both the NE-SW- and the E-W-trending faults post-date the Triassic Pingo Dal Group and are sealed by the dark mudstones of the Fosdalen Formation (Fig. 7B).

The stratigraphic successions in this small area record two episodes of block tilting. Bedding of the PermianTriassic strata dips $22-26^{\circ}$ toward the west, while the Fosdalen mudstones dip $12^{\circ}$ to the west. Back-tilting of strata shows that the latter tilting most likely relates to the movement along the Permpasset Fault, which displays more than $400 \mathrm{~m}$ offset, while the earlier tilting probably occurred during Early Cretaceous rifting. Jurassic strata display similar dips (23-26 towards the east) to the Permian-Triassic succession, but as the contact between these units is faulted, their relationship cannot be resolved. According to the data presented here and the cross-cutting relationships, the NE-SW-orientated fault is the only Early Cretaceous fault as it post-dates Oxfordian strata and pre-dates mid-Cretaceous mudstones. Early Cretaceous activity of the Permpasset Fault was supposed by Haller (1971) and Surlyk \& Korstgård (2013). The Permpasset Horst, as defined here, was interpreted as the footwall crest of a tilted fault block related to the Early Cretaceous rifting. We cannot exclude Cretaceous, or earlier, activity on the Permpasset Fault, but no direct evidence for earlier movements is available. The geometry of the fault-bounded Permapasset Horst indicates that it was a structural high located in the central 

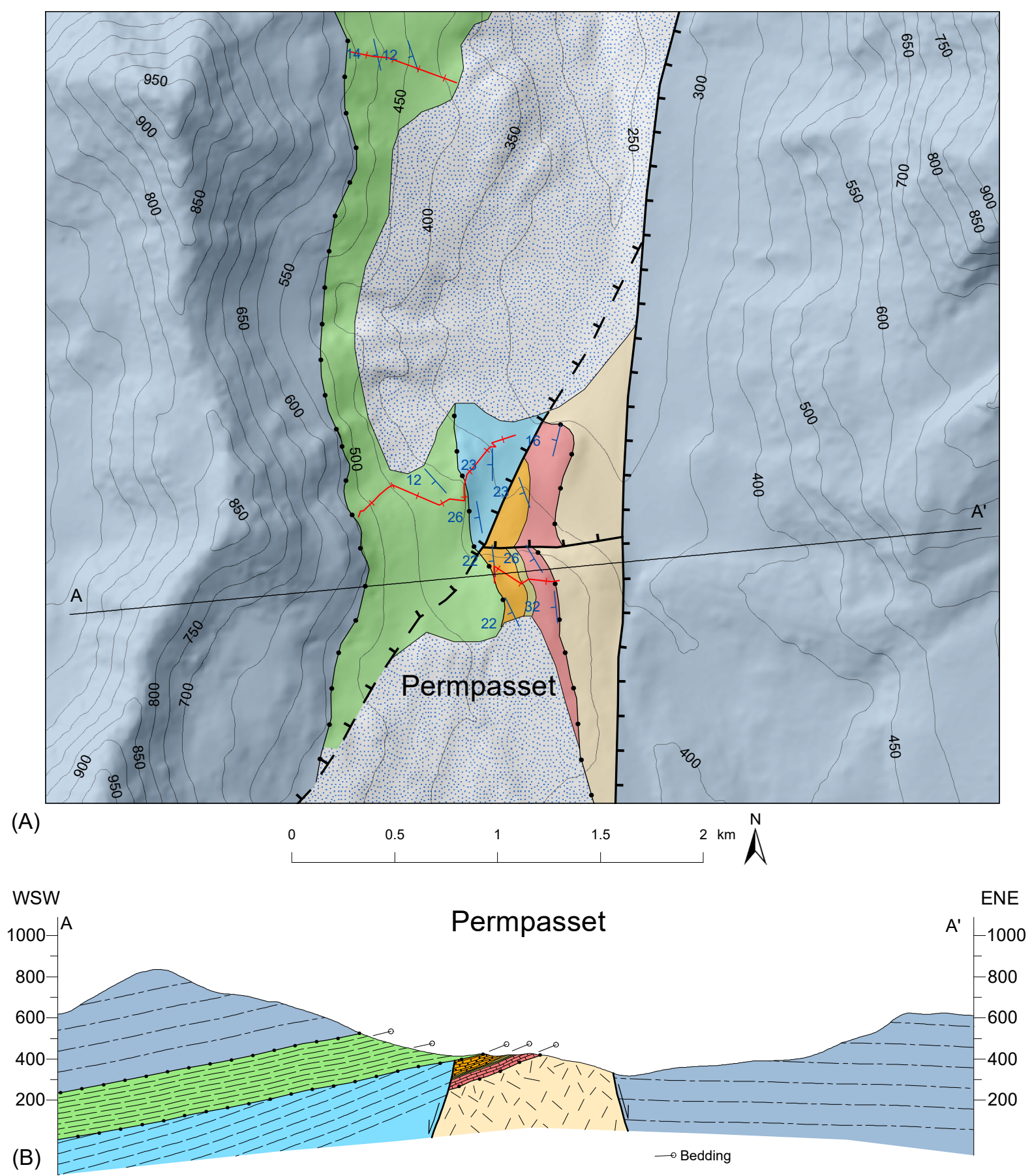

\section{Legend}
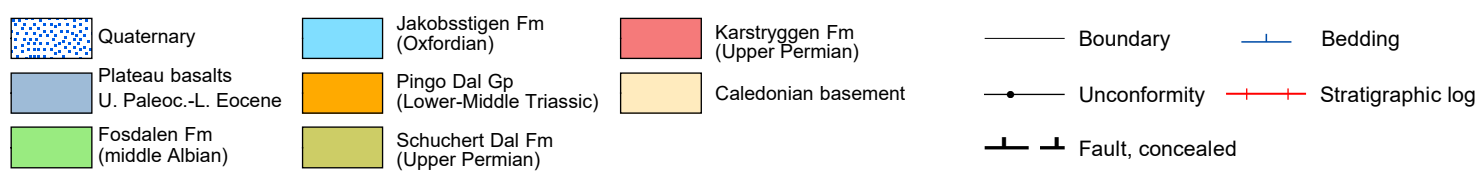

Fig. 7 Geological map of the Permpasset region and associated cross-section. A: Detailed geological map of Permpasset from fieldwork and 3D-photogeology. All heights given are metres a.s.l. Caledonian migmatites are unconformably overlain by upper Permian limestones of the Karstryggen Formation followed by a sandy succession of the Schuchert Dal Formation (not possible to distinguish in the northern portion of the outcrop due to erosion) and red beds of the Pingo Dal Group. Mid-Albian mudstones of the Fosdalen Formation unconformably cover both the Pingo Dal Group and Jakobsstigen Formation and post-date the NE-SW-trending normal fault. The N-S-trending Permpasset Fault was active in Palaeogene times as shown by almost $400 \mathrm{~m}$ offset of Plateau basalts to the east and responsible for the westward tilting of the successions. B: WSW-ENE geological cross-section of Permpasset showing structural relationships and the geometry of the fault-bounded Permpasset Horst. 
part of the Wollaston Forland Basin and associated with first-order N-S-trending faults and segmented by second-order NE-SW faults. The horst was active during Early Cretaceous rifting and unconformably draped by mudstones during the post-rift thermal subsidence before being uplifted again in Palaeogene times, subsequent to the emplacement of the Plateau basalts. The horst structure described from Geographical Society $\varnothing$ by Andrews \& Decou (2019) and Andrews et al. (2020a) contains a number of similarities with the Permpasset Horst and illustrates that structures of this nature may be relatively common.

\section{Discussion and conclusions}

The northward extent, and the nature of, Palaeozoic and Mesozoic facies in East Greenland hold important implications for palaeogeographic reconstructions and our understanding of adjacent offshore regions. Jurassic and Cretaceous strata can be traced northward up the East Greenland coast to just north of $76^{\circ}$. However, the nature and the extent of the Permian and Triassic strata are less well known. The exposures described here provide one of the most northern exposures of Permian strata and a candidate for the most northerly Triassic strata yet described from East Greenland.

Although the Permian succession is much condensed, the Karstryggen Formation (including a potential correlative of the Wegner Halvø Formation) and the Schuchert Dal Formation are recognised. In both instances, these appear to reflect relatively shallow-water conditions, with the deeper water source rock facies of the Ravnefjeld Formation being absent. Christiansen et al. (1993) noted that only the lower two sequences (Karstryggen Formation and the Wegner Halvø/ Ravnefjeld formations) described by Surlyk et al. (1986) could be traced northwards, with reference to their work on Clavering $\varnothing$, suggesting that a more prolonged period of erosion occurred during the latest Permian - earliest Triassic in this region. However, the identification of the Schuchert Dal Formation in Permpasset provides evidence for the northward continuation of this uppermost Permian sequence. Therefore, rather than the suggested northward increase in erosion in the latest Permian - earliest Triassic, the distribution of the Schuchert Dal Formation may be primarily the product of palaeogeographic or palaeoenvironmental controls on its development. Certainly, a position within the basin where clastic material is available would have provided a primary control on its development. In terms of the distribution of Permian strata on Wollaston Forland, Surlyk \& Korstgård (2013) suggest a north-eastward thinning and onlap of the Caledonian basement. This does not appear to be borne out by geological maps of the region (Fig. 1) or our mapping (Fig. 7). Indeed, with the few exposures available, it is extremely difficult to reconstruct the potential subcrop of Permian or Triassic strata, although in the north of Wollaston Forland, the basement is directly overlain by Jurassic and Cretaceous strata. To what extent thin Permian, or Triassic, deposits could have been eroded from uplifted regions, as those we now see, are, of course, unknown. Indeed, Haller (1971, fig. 145) appears to suggest that Permian strata blanketed the whole region prior to rifting and erosion during the Triassic. The discovery of reworked Triassic palynomorphs in the Jurassic succession at Jurakløft, described above, provides evidence for the erosion suggested by Haller (1971) and constrains its timing as Late Triassic to early Jurassic. When considered in relation to the adjacent offshore basins, the northward continuation of the Permian carbonates is consistent with what has been documented on the mid-Norwegian continental shelf (Bugge et al. 2002; Müller et al. 2005) and predicted to exist on the East Greenland Shelf (Rowan \& Jarvie 2020).

Previously, the most northerly Triassic strata in East Greenland were mapped as occurring on Clavering $\varnothing$, a short distance to the south of the sections described here, where deep marine clastics of the Wordie Creek Formation overlie the Permian succession. The Wordie Creek Formation dominates the northern extremities of the Triassic outcrop with the northernmost continental Triassic occurring on Laplace Bjerg, Geographical Society $\varnothing, 73^{\circ} \mathrm{N}$ (Andrews et al. 2019, 2020a). Therefore, the presence of continental Triassic (Pingo Dal Group) on Wollaston Forland $\left(74^{\circ} 22^{\prime} \mathrm{N}\right)$ significantly expands the extent of known continental facies of this age and suggests similar facies might be found in adjacent offshore basins. It should be remembered that the assignation of these facies to the Triassic is largely on the basis of their lithology, and the difficulty in placing such a continental succession within the Late Permian or Jurassic stratigraphy. Therefore, although an Early Triassic age, comparable to the Pingo Dal Group elsewhere, would seem most likely, a later Triassic age cannot be ruled out. The presence of reworked Triassic (Carnian) palynomorphs within the Jurassic certainly suggests that Triassic cover was more extensive than the single outcrop identified here. This would be consistent with the more complete Triassic successions recorded on the East Greenland Shelf (Rowan \& Jarvie 2020) and the conjugate mid-Norwegian Shelf (Müller et al. 2005). Resolving the controls on the uplift and erosion is difficult on the data available. It might be considered that Late Triassic - Early Jurassic erosion in the region was the result of rift flank uplift and was, therefore, localised around the basin margins. However, an apparently significant change in fault orientation occurs between the Triassic (NE-SW) and Jurassic (NNW-SSE) in East Greenland (Surlyk 2003; 
Guarnieri et al. 2017; Andrews et al. 2020b), and therefore, some form of structural re-organisation might be inferred, which could have resulted in uplift and erosion. A change in basin configuration is also recognised at this time in the Barents Sea and is attributed to the development of the Novaya Zemlya Fold and Thrust Belt (Müller at al. 2019). Although it would be rather far afield for these events to have affected East Greenland, it does demonstrate that significant tectonic events were occurring at this time in the region, and therefore, related adjustments in stress fields could have contributed to the development of the observed hiatus.

The Permpasset Horst, which provides the exposure of the units described above, is defined in the east by the Permpasset Fault, and to the west by a NE-SW-aligned fault. These faults converge to the north. A further fault aligned E-W cuts the Permpasset Horst but displays relatively limited displacement. The NE-SW fault and the E-W fault post-date the Jurassic and Triassic, respectively, and the former is sealed by the Albian Fosdalen Formation. Their formation is, therefore, most likely related to Early Cretaceous rifting. Following the rifting, a hiatus surface was developed and was subsequently draped with mid-Albian strata of the Fosdalen Formation, during the post-rift thermal subsidence. Movement on the Permpasset Fault can be demonstrated to postdate Eocene basalt emplacement, but this does not preclude earlier episodes of movement. Of further interest is the presence of sandstone clasts in the pebbly conglomerate at the base of the Jurassic section as these may suggest that the Permian and Triassic sediments were exposed and being eroded during the Jurassic and, therefore, imply that uplift of the region had already taken place in some form.

Glendonites are found along the basal hiatus surface, which marks the base of the Cretaceous succession. This is the first record of glendonites in the Cretaceous of East Greenland, and these likely relate to the late Aptian - Early Albian cooling event that is recorded throughout the Arctic (Rogov et al. 2017). This would suggest that the glendonites were, in fact, derived from older Cretaceous strata during the generation of the hiatus surface.

Finally, the presence of Permian and Triassic clastic strata, in the crestal region of a major horst structure, that are, in turn, draped with Cretaceous siltstonesmudstones, provides an important analogue for offshore hydrocarbon traps, expanding on the models presented by Surlyk \& Korstgård (2013).

\section{Acknowledgments}

This work was undertaken during a GEUS and MIERL joint co-ordinated Wollaston Forland regional mapping project. Ashton Embry and Tore Grane Klausen are thanked for their constructive reviews.

\section{Funding statement}

GEUS and MIERL joint funded the project.

\section{Competing interests}

The authors declare no competing interests.

\section{Author contributions}

SDA: field data collection, writing and conceptualisation. $\mathrm{HNH}$ : field data collection, palynological analysis and manuscript editing. PG: field data collection, mapping (field and photo) and writing (contribution). KD: palynological analysis. SL: palynological analysis. PA: manuscript editing.

\section{References}

Andrews, S.D. \& Decou, A. 2019: The Triassic of Traill $\varnothing$ and Geographical Society $\varnothing$, East Greenland: Implications for North Atlantic palaeogeography. Geological Journal 54(4), 2124-2144. https://doi.org/10.1002/ gj.3287

Andrews, S.D., Decou, A., Braham, B., Kelly, S.R.A., Robinson, P., Morton, A., Marshall, J.E.A. \& Hyden, F. 2020a: Exhumed hydrocarbon traps on the North Atlantic Margin: Stratigraphy, palaeontology, provenance and bitumen distribution, an integrated approach. Basin Research 32(5), 1213-1233. https://doi.org/10.1111/bre.12424.

Andrews, S.D., Kelly, S.R., Braham, W. \& Kaye, M. 2014: Climatic and eustatic controls on the development of a Late Triassic source rock in the Jameson Land Basin, East Greenland. Journal of the Geological Society 171(5), 609-619. https://doi.org/10.1144/jgs2013-075

Andrews, S.D., Morton, A.C. \& Decou, A. 2020b: Mid to Late Triassic evolution of the Jameson Land Basin, East Greenland. Geological Magazine. 158(5), 930-949 https://doi.org/10.1017/S001675682000093X

Bjerager, M., Alsen, P., Bojesen-Koefoed, J., Fyhn, M.B., Hovikoski, J., Ineson, J., Nøhr-Hansen, H., Nielsen, L.H., Piasecki, S. \& Vosgerau, H. 2020: Cretaceous lithostratigraphy of North-East Greenland. Bulletin of the Geological Society of Denmark 68, 37-93. https://doi.org/10.37570/ bgsd-2020-68-04

Bugge, T., Ringas, J.E., Leith, D.A., Mangerud, G., Weiss, H.M. \& Leith, T.L. 2002: Upper Permian as a new play model on the mid-Norwegian continental shelf: Investigated by shallow stratigraphic drilling. AAPG bulletin 86(1), 107-127. https://doi. org/10.1306/61EEDA4E-173E-11D7-8645000102C1865D

Christiansen, F.G., Piasecki, S., Stemmerik, L. \& Telnæs, N. 1993: Depositional environment and organic geochemistry of the Upper Permian Ravnefjeld Formation source rock in East Greenland. AAPG bulletin 77(9), 1519-1537. https://doi.org/10.1306/ bdff8ede-1718-11d7-8645000102c1865d

Clemmensen, L.B. 1980a: Triassic lithostratigraphy of East Greenland between Scoresby Sund and Kejser Franz Josephs Fjord. Bulletin Grønlands Geologiske Undersøgelse 139, 56 pp. https://doi.org/10.34194/ bullggu.v139.6681

Clemmensen, L.B. 1980b: Triassic rift sedimentation and palaeogeography of central East Greenland. Bulletin Grønlands Geologiske Undersøgelse 136, 72 pp. https://doi.org/10.34194/bullggu.v136.6678

Clemmensen, L.B., Kent, D.V., Mau, M., Mateus, O. \& Milàn, J. 2020: Triassic lithostratigraphy of the Jameson Land Basin (central East Greenland), with emphasis on the new Fleming Fjord Group. Bulletin of the Geological Society of Denmark 68, 95-132. https://doi.org/10.37570/ bgsd-2020-68-05-rev

Dal Corso, J. et al. 2020: Extinction and dawn of the modern world in the Carnian (Late Triassic). Science Advances 6(38), eaba0099. https://doi. org/10.1126/sciadv.aba0099

Escher, J.C. 2001: Geological map of Greenland, 1:500 000, Kong Oscar Fjord, sheet 11. Copenhagen: Geological Survey of Denmark and Greenland.

Guarnieri, P., Brethes, A. \& Rasmussen, T.M. 2017: Geometry and kinematics of the Triassic rift basin in Jameson Land (East Greenland). Tectonics 36(4), 602-614 https://doi.org/10.1002/2016tc004419

Haller, J. 1971: Geology of the East Greenland Caledonides, 413 pp. London: Interscience.

Kreiner-Møller, M. \& Stemmerik, L. 2001: Upper Permian lowstand fans of the Bredehorn Member, Schuchert Dal Formation, East Greenland. In: Martinsen, O.J. \& Dreyer, T. (eds): Sedimentary Environments Offshore Norway - Palaeozoic to Recent. Norwegian Petroleum 
Society Special Publications 10, 51-65. https://doi.org/10.1016/ s0928-8937(01)80008-4

Maync, W. 1942: Stratigraphie und Faziesverhältnisse der oberpermiscen Ablagerungen Ostgrönlands (olim "Oberkarbon-Unterperm") zwischen Wollaston Forland und dem Kejser Franz Josephs Fjord. Meddelelser om Grønland 115(2), 128.

Mueller, S., Hounslow, M.W. \& Kürschner, W.M. 2016: Integrated stratigraphy and palaeoclimate history of the Carnian Pluvial Event in the Boreal realm; new data from the Upper Triassic Kapp Toscana Group in central Spitsbergen (Norway). Journal of the Geological Society 173, 186-202. https://doi.org/10.1144/jgs2015-028

Müller, R., Klausen, T.G., Faleide, J.I., Olaussen, S., Eide, C.H. \& Suslova, A. 2019: Linking regional unconformities in the Barents Sea to compression-induced forebulge uplift at the Triassic-Jurassic transition. Tectonophysics 765, 35-51. https://doi.org/10.1016/j.tecto.2019.04.006

Müller, R., Nystuen, J.P., Eide, F. \& Lie, H. 2005: Late Permian to Triassic basin infill history and palaeogeography of the Mid-Norwegian shelf - East Greenland region. In: Wandås et al. (eds): Onshore-Offshore Relationships on the North Atlantic margin. Norwegian Petroleum Society Special Publications 12, 165-189. https://doi.org/10.1016/ S0928-8937(05)80048-7

Nøhr-Hansen, H. 1993: Dinoflagellate cyst stratigraphy of the Barremian to Albian, Lower Cretaceous, North-East Greenland. Bulletin Grønlands Geologiske Undersøgelse 166, 177. https://doi.org/10.34194/ bullggu.v166.6722

Nøhr-Hansen, H., Piasecki, S. \& Alsen, P. 2020: A Cretaceous dinoflagellate cyst zonation for NE Greenland. Geological Magazine 157(10), 1658-1692. https://doi.org/10.1017/s0016756819001043

Olsen S.D \& Jakobsen K.G. 2018: Photo Flying in North East Greenland 2017. Danmarks og Grønlands Geologiske Undersøgelse Rapport 2018/14, $19 \mathrm{pp}$

Paterson, N.W. \& Mangerud, G. 2015: Late Triassic (Carnian-Rhaetian) palynology of Hopen, Svalbard. Review of Palaeobotany and Palynology 220, 98-119. https://doi.org/10.1016/j.revpalbo.2015.05.001

Paterson, N.W. \& Mangerud, G. 2020: A revised palynozonation for the Middle-Upper Triassic (Anisian-Rhaetian) Series of the Norwegian Arctic. Geological Magazine 157(10), 1568-1592. https://doi. org/10.1017/s0016756819000906

Piasecki, S., Larsen, M., Therkelsen, J. \& Vosgerau, H. 2004: Jurassic dinoflagellate cyst stratigraphy of Hold with Hope, North-East Greenland. Geological Survey of Denmark and Greenland Bulletin 5, 73-88. https://doi.org/10.34194/geusb.v5.4808

Poulsen, N.E., Gudmundssonn, L., Morten Hansen, J. \& Husfeldt, Y. 1990. Palynological preparation techniques, a new Macerationtank-method and other modifications. Geological Survey of Denmark, Danmarks Geologiske Undersøgelse Series C 10, 23 pp. https://doi.org/10.34194/ seriec.v10.7104

Rogov, M.A., Ershova, V.B., Shchepetova, E.V., Zakharov, V.A., Pokrovsky, B.G. \& Khudoley, A.K. 2017: Earliest Cretaceous (late Berriasian) glendonites from Northeast Siberia revise the timing of initiation of transient Early Cretaceous cooling in the high latitudes. Cretaceous Research 71, 102-112. https://doi.org/10.1016/j.cretres.2016.11.011

Rowan, M.G. \& Jarvie, A. 2020: Crustal extension and salt tectonics of the Danmarkshavn Ridge and adjacent basins, NE Greenland. Marine and Petroleum Geology 117, 104339. https://doi.org/10.1016/j. marpetgeo.2020.104339

Seidler, L., Steel, R., Stemmerik, L. \& Surlyk, F. 2004: North Atlantic marine rifting in the Early Triassic: New evidence from East Greenland. Journal of the Geological Society 161(4), 583-592. https://doi. org/10.1144/0016-764903-063

Sørensen, E.V. \& Dueholm, M. 2018: Analytical procedures for 3D mapping at the Photogeological Laboratory of the Geological Survey of Denmark and Greenland. Geological Survey of Denmark and Greenland Bulletin 41, 99-104. https://doi.org/10.34194/geusb.v41.4353

Sørensen, E.V. \& Guarnieri, P. 2018: Remote geological mapping using 3D photogrammetry: An example from Karrat, West Greenland. Geological Survey of Denmark and Greenland Bulletin 41, 63-66. https:// doi.org/10.34194/geusb.v41.4343

Stemmerik, L. 2001: Sequence stratigraphy of a low productivity carbonate platform succession: The upper Permian Wegener Halvø formation, Karstryggen area, East Greenland. Sedimentology 48(1), 79-97. https://doi.org/10.1111/j.1365-3091.2001.00352.x

Surlyk, F. 1990: Timing, style and sedimentary evolution of Late Palaeozoic-Mesozoic extensional basins of East Greenland. Geological Society (London) Special Publications 55(1), 107-125. https://doi. org/10.1144/gs/.sp.1990.055.01.05

Surlyk, F. 2003: The Jurassic of East Greenland: A sedimentary record of thermal subsidence, onset and culmination of rifting. Geological Survey of Denmark and Greenland Bulletin 1, 659-722. https://doi. org/10.34194/geusb.v1.4674

Surlyk, F., Hurst, J.M., Piasecki, S., Rolle, F., Scholle, P.A., Stemmerik, L. \& Thomsen, E. 1986: The Permian of the western margin of the Greenland Sea - A future exploration target. In: Halbouty, M.T. (ed.): Future Petroleum Provinces of the World. AAPG Memoirs 40, 629-659. https://doi.org/10.1306/ad461791-16f7-11d7-8645000102c1865d

Surlyk, F. \& Korstgård, J. 2013: Crestal unconformities on an exposed Jurassic tilted fault block, Wollaston Forland, East Greenland as an analogue for buried hydrocarbon traps. Marine and Petroleum Geology 44, 82-95. https://doi.org/10.1016/j.marpetgeo.2013.03.009

Vigran, J.O., Mangerud, G., Mørk, A., Worsley, D. \& Hochuli, P.A. 2014: Palynology and geology of the Triassic succession of Svalbard and the Barents Sea. Geological Survey of Norway Special Publication 14, 269 pp.

Vosgerau, H., Bojesen-Koefoed,J.A., Petersen, H.I. \&Surlyk, F. 2000:Forest fires, climate, and sea-level changes in a coastal plain-shallow marine succession (Early-Middle Oxfordian Jakobsstigen Formation, NorthEast Greenland). Journal of Sedimentary Research 70(2), 408-418. https://doi.org/10.1306/2dc40919-0e47-11d7-8643000102c1865d 